\title{
An Analysis of Teachers Questioning Strategy at the Computer Engineering Class of SMKN 7 Luwu Utara
}

\author{
Tsamratul'aeni dan Neneng Fidya \\ Universitas Cokroaminoto Palopo \\ tsamratulaeni3@gmail.com, nenengfidya21718@gmail.com
}

\begin{abstract}
The objective of this research is to find out the teachers' questioning strategy in teaching English at SMKN 7 Luwu Utara. The method that was applied in this research is a descriptive qualitative method. There were 2 English teachers as the sample of this research. Data collection of this research through interview and questionnaire. The result of data analysis showed that the teachers used questioning strategies by applying some types of question in each sessions of teaching. During the interview the researcher found that the first teacher only used a probing question and divergent question, while the second teacher only used a higher order question. So, from the whole between the first teacher and the second teacher after the researcher analyzed from the interview and questionnaire, the researcher found that the questioning strategies used by the teacher were probing questions, divergent questions and higher order questions. As for the strategy question that often appears or is often used by teachers, namely the probing question strategy.

Keywords: English Teachers' question and Questioning strategy.
\end{abstract}

\section{Introduction}

In the process of teaching English, there is a process called asking or giving questions. It can be from teacher to students or from students to the teacher. Student questioning should be used in the questioning strategy. The questioning strategy is a way of asking questions to students in teaching. In the teaching and learning process, teachers need to understand students' abilities and their understanding of the material being studied. In addition, teachers must ask questions before or after teaching to understand student learning outcomes. Therefore, there must be interaction between teacher and students, and then student feedback. Sujariati \& Rahman, (2016)

According to Prasetyawati (2015) asking questions to the students is an important part of the teaching and learning process because it can stimulate students to learn, gain knowledge and improve their critical thinking. In order to understand, students must search for meaning. In order to search meaning, students must have the opportunity to form and ask the question (Brooks \& Brooks, 1993 cited in Prasetyawati 2015).

Computer Engineering is a special discipline that combines Electrical Engineering and Computer Science. So here, the researcher wants to know kind of questions are given by the teacher to students, especially to students majoring in Computer Engineering. Based on the explanation above, the researcher is 
Jurnal Onoma: Pendidikan, Bahasa dan Sastra PBSI FKIP Universitas Cokroaminoto Palopo Volume 7 Nomor 1 Tahun 2021
ISSN 2443-3667 (print)

ISSN 2715-4564 (online)

interested in conducting research which entitled An Analysis of Teacher's Questioning Strategies at The Computer Engineering Classroom of SMKN 7 Luwu Utara.

\section{Review of Related Literature Definition of Questions}

Questions are sentences, phrase or gestures that seek information through answers. This means that the question is when the teacher says something like a word, phrase or sentence that the interlocutor or audience needs to answer. Several experts have proposed several definitions of the term. According to Linch (in Sujariati\& Rahman:109) a problem is an order or question expression that is used to obtain information or answer or test knowledge. In other words, when people express sentences to others, involving expressions of orders and questions to obtain information or responses means a problem.

The question is any sentence with an interrogative function. In classroom learning activities, teacher questions are defined as instructional instructions or stimuli that convey to students the elements of content to be studied and the direction of what they do and how to do it. According to Wragg and Brown (2001:54) problems are an important element in designing teaching and improving learning. Farmer (2006:2) also shows that problems are skills that connect the unknown with known knowledge. Therefore, asking questions in learning activities in class is an important thing to do.

From these definitions, we can generalize that the word question refers to any idea that requires a response from the listener or audience. Above all, in classroom settings, teacher questions are defined as instructional cues or stimuli that convey to student's content elements to be learned and directions for what they are to do and how these elements to be learned and directions for what they are to do and how they are to do it.

\section{Definition of Questioning Strategy}

Brown and Edmonsos (1985:2) demonstrated that questioning strategiesare one of the important tools for developing students' learning abilities, which can help teachers develop their own strategies for improving students' employability and thinking skills. This means that we cannot ignore that questioning strategies are very important for both teachers and students.

According to Fries Gather. J. (2008:4), the questioning strategy is one of the most important aspects of teaching. It enables the counselor to increase students' ability to grasp and grasp knowledge, and allows students to seek clarification and help. This means that by asking questions, the teacher can find out what students know and what they don't. Questions can help teachers and students in teaching.

From this definition, it can be seen that the questioning strategy is a way of asking questions to students to achieve teaching goals. In the teaching and 
Jurnal Onoma: Pendidikan, Bahasa dan Sastra PBSI FKIP Universitas Cokroaminoto Palopo Volume 7 Nomor 1 Tahun 2021
ISSN 2443-3667 (print)

ISSN 2715-4564 (online)

learning process, teachers need to understand students' abilities and their understanding of the material being studied.

\section{Types of questioning strategy}

The importance of the questioning strategy in classroom teaching is to facilitate the application of various teaching methods and techniques. A variety of questioning strategies can help students take more responsibility for their own learning and participate in the teaching process. The key to the teacher's questioning strategy is to create a more interactive, active and collaborative learning environment. The teacher also uses the teacher questioning strategy as part of the learning assessment to determine the structure, organization, and best way to prevent new learning. The following list is a list of question types that teachers can use to analyze their asking strategies and ask thoughtprovoking questions.

a) Probing Question

Inquiry questions are a series of questions that require students to go beyond the initial answer. The teacher's questions are then formed based on student responses, as explained by P.E Blosser (1975) (Faculty et al., 2017). In this case, Jacobsen and Dulany (in Syarifah, 2017: 11) define detection as a questioning technique where students can give answers more actively and provide a lot of information to get more inclusive answers. When implementing this strategy, teachers have identified distraction and encouragement techniques. The first involves increasing the number of students, while the second tackles wrong answers. When students' answers are correct but insufficient due to lack of depth, another situation arises. Let's take a look at this strategy.

The teacher begin, "do you think trees are important to the land" (pause)

$$
\begin{gathered}
\text { "Amelia?" } \\
\text { "Yes." } \\
\text { "Why, Amelia?" } \\
\text { "Because they help hold things together." }
\end{gathered}
$$

The purpose of this strategy is for students to prove or further explain their answers, thereby increasing the depth of the discussion. It also helps keep students away from surface reactions. Usually, teachers will not let students go beyond simple yes or no answers. Teachers need to provide more opportunities for their students to process information, why, how, and best way. In other words, students not only gain experience in handling higher-level assignments, but they also get a greater sense of success.

In this strategy, problem detection is divided into two techniques, namely redirection and prompting. According to Jacobsen and Dulaney (quoted in Syarifah, 2017: 13), redirection is a way to reduce teacher speech and attempt to 
Jurnal Onoma: Pendidikan, Bahasa dan Sastra PBSI FKIP Universitas Cokroaminoto Palopo Volume 7 Nomor 1 Tahun 2021
ISSN 2443-3667 (print)

ISSN 2715-4564 (online)

eliminate personal domination in class discussions. In other words, this technology can maximize students' verbal communication.

In addition, it can be used to call on non-volunteers, thereby expanding the scope of the discussion. Let's take a closer look at this technology.

Teacher: "what are them of Hemingway old man and the sea?"

Samuel: "Its abound old man's courage in catching a fish."

Teacher: "ahmad do you agree?" or "Ahmad can you elaborate Samuel's answer."

In this case the teacher will direct the same question to other students to get various answers. This strategy can create active classroom learning activities, as well as inspire students to show confidence and abilities. The difference between redirects and prompts is provided by the teacher with encouragement to help students solve the answers.

Based on the explanation above we know that, probing questions can motivate students to understand the problem more deeply so that students are able to find the intended answers. During the process of searching and finding answers to these problems, they try to connect the knowledge and experience they already have with the questions to be answered.

b) Factual Question

Factual questions are questions that require students to remember specific information they have learned. The strategy is to model simple exploratory questions to gather information. In this questioning strategy, the teacher will use several types of questions, such as what, who, where, when and why to develop simple information-gathering responses based on the information provided.

The advantage of this questioning strategy is to encourage students to do exercises and understanding, which can be extended to reasoning and hypotheses. In addition, it will create curious characters and thoughts as well as self-reflection learning methods. There are two types of fact questions, namely simple pieces of information, and facts arranged in a logical order (sequence of events).

According to Jessica (in Syarifah, 2017: 15), truth questions serve to convey simple information and answer the facts, arranging them in a logical order. Here is an example:

a. Simple bit of information

Teacher: "Who was the leader of the Free French forces during W.W.II?"

"Who is the main character in Margaret Mitchells's novel, Gone with the Wind?

"During which century did Shakespeare live?"

"What is the Spanish verb meaning to run?"

b. Fact organizes into logical order.

"What are the steps a bill goes through before it becomes a law?" 
Jurnal Onoma: Pendidikan, Bahasa dan Sastra PBSI FKIP Universitas Cokroaminoto Palopo Volume 7 Nomor 1 Tahun 2021
ISSN 2443-3667 (print)

ISSN 2715-4564 (online)

"How where the American and French forces able to bottle up Cornwall and the British at Yorktown?"

"How did Robinson Crusoe react when he discovered footprints in the sand?"

"What is the commercial method for producing hydrochloric acid?"

Those example are taken from the book of Teachers' questioning strategy by Blosser (in Syarifah, 2017:16).

Based on the explanation above, factual questions can simplify complicated topics, as well, by breaking them into more digestible elements.

c) Divergent Question

According to Jacobsen and Dulaney (in Syarifah, 2017: 16), divergent questions are questions that allow students to get a variety of unique answers that are not entirely determined by known and remembered information. P.E Blosser (1979) also defines divergent questions as questions without right or wrong answers, but encourages exploration of possibilities. It takes concrete and abstract ideas to arrive at the right response.

Example:

"What might happen if Congress passes a law preventing the manufacture and sale of cigarettes in the United States?"

"How would the story have been different if John had been a tall, strong boy instead of disabled?"

"If you were stuck on a desert island and the only tool you had was a screwdriver, what use might you make of it?"

"In what ways would history have been changed had the Spanish Armada defeated the English in 1588?"

With this strategy, the teacher will notice that many students have answered the question posed by the teacher in various ways. The problem is so big that it is impossible for the student to give a correct answer. No answer is completely correct, but nothing can be called wrong. In short, different problems allow for a variety of acceptable and appropriate response actions. In addition, they usually require a higher response rate.

Based on the explanation above, divergent question allows students to explore different avenues and create many different variations and alternative answers or scenarios.

d) Higher Order Question

According to P.E Blosser (in Syarifah, 2017: 17) high-level questions are questions that require students to find out the answer rather than memorizing the answer. It is necessary to summarize fact-related content in a meaningful way. Hunkin's research (in Syarifah, 2017: 16) shows the purpose of using this strategy, where the use of these questions shows that the higher level of achievement increases, while the lower level does not decrease. Let's look at the situation and see how the teacher asks higher level questions. 
Jurnal Onoma: Pendidikan, Bahasa dan Sastra PBSI FKIP Universitas Cokroaminoto Palopo Volume 7 Nomor 1 Tahun 2021
ISSN 2443-3667 (print)

ISSN 2715-4564 (online)

As Peterson and Taylor said, high-level questions require students to think deeper and describe their oral responses to literature (in Syarifah, 2017: 16). When teachers ask high-level questions, they may find that the questions are difficult for students to answer, or students can only provide simple answers or two words. Then the teacher can respond by giving an example of how to give a higher response.

a. Evaluation: Requires judgment, value or choice based upon comparing of ideas or objects to established standards.

Ex: "Which of the two books do you believe contributed most to an understanding of the Victorian era? Why?" "Assuming equal resources, who would you, rate as the most skillful general, Robert E. Lee or Ulysses S. Grant? Why?

b. Inference: Inductive or deductive reasoning is required.

Induction: Find general principles from a specific set of facts.

Deduction: a logical operation to test the value of generalizations There are special problems.

Ex: "We have examined the qualities these world leaders have in common.

What might we conclude, in general, about qualities necessary for

leadership? Why?" (Inductive)

"If the temperature of the gas remains the same, but gas is taken to an altitude of 4000 feet higher, what happens to the pressure of the gas? Why?"

(Deductive). As stated by Blosser (in Syarifah, 2017:17) in his book teachers' questioning strategy.

Based on the explanation above, one of the advantages of higher order questions is that they encourage learners to use their creativity without running the risk of being judged.

\section{Teacher's Questioning Strategy}

Guest (in Sujariati, 2016:109) stated that questioning strategy is one of the important tools to extending students' learning which can help teachers develop their own strategies to enhance the students work and thinking. In the other hands, teacher questioning is very important for teacher and students. According to Harvey (2000:8) questioning strategy is most effective when it allows pupils to become fully involved in the learning process. He states that while the lesson is planning, it is absolutely vital that teachers think about the types of question will be asked to students. So questioning strategies will help a teacher to plan questions and answers session effectively when the teacher plays the questions effectively based on the students need and the question types to be involved fully students' interaction.

From the definitions, we know that teacher's questioning strategy is the teacher's approach to students as a whole related to the implementation of 
ideas, planning, and execution of an activity to support the course of teaching and learning.

\section{Why Questioning is used}

There are many reasons for teachers to ask students some questions, whether these questions are for individual students or for the entire class. The teacher uses a variety of questions and question types as a questioning strategy, which can not only encourage classroom interaction, but also encourage students to communicate in real life, establish closer contact with students, and help students deal with problems. Due to the limited vocabulary, it is difficult to express oneself. These questions are often used at the end of the course, but sometimes at the beginning and in the middle of the teaching process. (Sujariati \& Rahman, 2016).

Teachers ask questions to students so that they are involved and stimulate deeper thinking about the topic being discussed. The questioning technique is one of the basic skills of good teaching (Adler, 1982). Therefore, in practicing good teaching skills, education may have to reach a level of knowledge and awareness that is hidden by learners to help learners reach new levels of thinking.

From the definitions, we know that questioning strategy can help teach to get students' attention in the learning process, besides questioning strategy can also increase students' enthusiasm for learning.

\section{Research Method \\ Research Design}

This research was descriptive qualitative research. It is to find out the an Analysis of Teacher's Questioning Strategies at the Computer Engineering Class of SMKN 7 Luwu Utara.

\section{Time and Location of the Research}

This research was conducted on November 2020 at SMKN 7 Luwu Utara.

\section{Population and Sample}

Population of this research were English teachers at the Computer Engineering Classroom of SMKN 7 Luwu Utara. This research used total sampling technique to determine the sample, that consist of two English teachers.

\section{Instrument of the Research}

The researcher used interview and questionnaire as the instrument to collect the data.

\section{Procedures of Collecting Data}

To collect the data, the researcher used procedures as follow:

\section{Interview}

The interview was used to collect data about the teacher's questioning strategy in teaching. The researcher met with the English teachers. Then, the 
Jurnal Onoma: Pendidikan, Bahasa dan Sastra PBSI FKIP Universitas Cokroaminoto Palopo Volume 7 Nomor 1 Tahun 2021
ISSN 2443-3667 (print)

ISSN 2715-4564 (online)

researcher gave ten questions to the English teachers, to get data about the teacher's questioning strategies in teaching and record it.

2. Questionnaire

The questionnaire is a research instrument consisting of a series of questions for the gathering information from respondents. The questionnaire was applied to collect data by giving several statements and the teacher answered using the words agree, strongly agree, disagree and strongly disagree

\section{Findings and Discussion \\ Findings}

1. Interview

That the interview consists of 5 questions, the researcher found the teacher used probing, divergent and higher order question. The data analysis aims to find out the information about the teacher's questions in learning English.

The first teacher:

\section{Questions}

1. How do you think about applying questioning strategies in teaching and learning process?

2. What kind of asking strategy that you use in class?

3. Is questioning strategy can make you more easy in teaching in front of class?

4. Is questioning strategy can motivate students in learning?

5. How do you know that questioning strategy that you use can motivate the students in teaching and learning process?

The first question is "How do you think about applying questioning strategies in teaching and learning process?". The teacher said that "questioning strategy is good strategy to know how the students' ability in learning. Whether the students understand the material or not.

The second question is "What kind of asking strategy that you use in class?". The teacher said that "I provide questions that require students to immediately spontaneously answer and give a variety of unique responses.

The third question is "Is questioning strategy can make you more easy in teaching in front of class?". The teacher said that "yes, that strategy can make teacher easy in teaching because while studying online, the teacher reduces the number of questions that will be asked of students because of insufficient time. So, the teacher prepares questions that are easy to understand".

The fourth question is "Is questioning strategy can motivate students in learning?". The teacher said that "sometimes the teacher motivate students 
Jurnal Onoma: Pendidikan, Bahasa dan Sastra PBSI FKIP Universitas Cokroaminoto Palopo Volume 7 Nomor 1 Tahun 2021
ISSN 2443-3667 (print)

ISSN 2715-4564 (online)

based on situation. Ex: There is student who quickly understood and there is no student who quickly understood".

The fifth question is "How do you know that questioning strategy that you use can motivate the students in teaching and learning process?". The teacher said that "if students told "paham bu" or "mengerti bu" it can be confirmed that the students really understand the material".

Based on the interview above, the researcher found several types of questioning strategies produced by the teacher, namely "spontaneously answer" which leads to a probing question and "give a variety of unique responses" which leads to a divergent question, and then "yes, that strategy can make it easier when I teach. Because during online learning questions/asking students are reduced due to insufficient time, so the teacher prepares questions that can make students immediately answer quickly" refers to probing question.

The second teacher:

\section{Questions}

1. How do you think about applying questioning strategies in teaching and learning process?

2. What kind of asking strategy that you use in class?

3. Is questioning strategy can make you more easy in teaching in front of class?

4. Is questioning strategy can motivate students in learning?

5. How do you know that questioning strategy that you use can motivate the students in teaching and learning process?

The first question is "How do you think about applying questioning strategies in teaching and learning process?". The teacher said that "with the questioning strategy in teaching and learning process, teacher can know students' ability. Whether students can answer the questions or not. If there are no questions in learning process, it cannot be effective".

The second question is "What kind of asking strategy that you use in class?". The teacher said that "usually I give students difficult questions so that students think more and when answering orally".

The third question is "Is questioning strategy can make you more easy in teaching in front of class?". The teacher said that "very easy for me because I don't need to explain many times".

The fourth question is "Is questioning strategy can motivate students in learning?". The teacher said that "yes, questioning strategy can make students motivated to study hard".

The fifth question is "How do you know that questioning strategy that you use can motivate the students in teaching and learning process?". The 
teacher said that "if I give a question, the students compete to raise their hands to answer the questions that I give".

Based on the interview above, the researcher just found one type of questioning strategy produced by the teacher, namely "usually I give questions to students in the form of questions that are quite difficult so that students can think more deeply and must answer verbally" which leads to a higher order question.

\section{Questionnaire}

The questionnaire in this research consists of ten questions. The aim of this questionnaire is to answer the second problem statement. This questionnaire gave to the teacher in class X 1 and class X 2 . There were two teachers who were respondents.

Researcher calculate the questionnaire based on the formula in chapter III and the researcher found the data of the teachers' responses. The data findings are presented in Table below.

The first teacher (class X TKJ 1)

\begin{tabular}{|c|c|c|c|}
\hline No & Item & Answer & Quantity \\
\hline 1. & $\begin{array}{l}\text { Questioning strategies in the teaching } \\
\text { and learning process are difficult to } \\
\text { apply. }\end{array}$ & Agree & 2 \\
\hline 2. & Apply a variety questioning strategies. & Disagree & 1 \\
\hline 3. & $\begin{array}{l}\text { The questioning strategy in the } \\
\text { teaching and learning process can } \\
\text { make it easier for you when teaching } \\
\text { in front of the class. }\end{array}$ & Agree & 2 \\
\hline 4. & $\begin{array}{l}\text { The questioning strategy can motivate } \\
\text { students to enthusiastic about }\end{array}$ & Agree & 2 \\
\hline 5. & learning. & Agree & 2 \\
\hline 6. & $\begin{array}{l}\text { The questioning strategy can improve } \\
\text { students' English skills. } \\
\text { The teacher adjusts the questions }\end{array}$ & Strongly agree & 1,5 \\
\hline 7. & $\begin{array}{l}\text { given to the learning material. } \\
\text { The use of question strategies in the } \\
\text { process of teaching English improves }\end{array}$ & Agree & 2 \\
\hline 8. & $\begin{array}{l}\text { the ability of teachers professionally. } \\
\text { The teacher asks questions from low }\end{array}$ & Strongly agree & 1,5 \\
\hline 9. & $\begin{array}{l}\text { level to high level. } \\
\text { The teacher experiences certain } \\
\text { obstacles when asking questions in }\end{array}$ & Agree & 2 \\
\hline 10. & $\begin{array}{l}\text { front of the class. } \\
\text { The teacher experience certain }\end{array}$ & Agree & 2 \\
\hline
\end{tabular}


obstacles in the application of question strategies in the teaching and learning process.

This item shows the teacher response about questioning strategies in the teaching and learning process are difficult to apply is agree, apply a variety questioning strategies is disagree, the questioning strategy in the teaching and learning process can make it easier for you when teaching in front of the class is agree, the questioning strategy can motivate students to enthusiastic about learning is agree, the questioning strategy can improve student's English skills is agree, the teacher adjusts the questions given to the learning material is strongly agree, the use of question strategies in the process of teaching English improves the ability of teachers professionally is agree, the teacher asks questions from low level to high level is agree, and the teacher experience certain obstacles in the application of question strategies in the teaching and learning process is agree.

The second teacher (class X T KJ 2)

\begin{tabular}{|c|c|c|c|}
\hline No & Item & Answer & Quantity \\
\hline 1. & $\begin{array}{l}\text { Questioning strategies in the teaching } \\
\text { and learning process are difficult to } \\
\text { apply. }\end{array}$ & Agree & 2 \\
\hline 2. & Apply a variety questioning strategies. & Disagree & 1 \\
\hline 3. & $\begin{array}{l}\text { The questioning strategy in the } \\
\text { teaching and learning process can } \\
\text { make it easier for you when teaching } \\
\text { in front of the class. }\end{array}$ & Agree & 2 \\
\hline 4. & $\begin{array}{l}\text { The questioning strategy can motivate } \\
\text { students to enthusiastic about }\end{array}$ & Strongly agree & 1,5 \\
\hline 5. & $\begin{array}{l}\text { learning. } \\
\text { The questioning strategy can improve }\end{array}$ & Agree & 2 \\
\hline 6. & $\begin{array}{l}\text { students' English skills. } \\
\text { The teacher adjusts the questions }\end{array}$ & Strongly agree & 1,5 \\
\hline 7. & $\begin{array}{l}\text { given to the learning material. } \\
\text { The use of question strategies in the } \\
\text { process of teaching English improves }\end{array}$ & Agree & 2 \\
\hline 8. & $\begin{array}{l}\text { the ability of teachers professionally. } \\
\text { The teacher asks questions from low }\end{array}$ & Strongly agree & 1,5 \\
\hline 9. & $\begin{array}{l}\text { level to high level. } \\
\text { The teacher experiences certain } \\
\text { obstacles when asking questions in }\end{array}$ & Agree & 2 \\
\hline
\end{tabular}


Jurnal Onoma: Pendidikan, Bahasa dan Sastra PBSI FKIP Universitas Cokroaminoto Palopo Volume 7 Nomor 1 Tahun 2021
ISSN 2443-3667 (print)

ISSN 2715-4564 (online)

10. front of the class.
The teacher experience certain
obstacles in the application of
question strategies in the teaching
and learning process.

This item shows the teacher response about questioning strategies in the teaching and learning process are difficult to apply is agree, apply a variety questioning strategies is disagree, the questioning strategy in the teaching and learning process can make it easier for you when teaching in front of the class is agree, the questioning strategy can motivate students to enthusiastic about learning is strongly agree, the questioning strategy can improve students' English skills is agree, the teacher adjusts the questions given to the learning material is strongly agree, the use of question strategies in the process of teaching English improves the ability of teachers professionally is strongly agree, the teacher asks questions from low level to high level is agree, the teacher experiences certain obstacles when asking questions in front of the class is agree and the teacher experience certain obstacles in the application of question strategies in the teaching and learning process.

We can know from the result that item 1,2, and 3 the teachers have the same answer. Then on the item 4 the answer is different. The first teacher answer agree, while the second teacher answer strongly agree. In item 5 the teachers have the same answer, and also on theitem 6 the teachers have the same answer, and then likewise in item 7 the answer is the same, and so on until item 10, both teachers have the same answer.

\section{Discussion}

Based on the teacher's question strategies at the findings, this section present the result of data analysis of interview and questionnaire related to the theory in chapter II. Furthermore, this section aims to find out the teacher questioning strategies in teaching English, based on the information that had been show on tables in findings.

The word question refers to any idea that requires a response from the listener or audience. Above all, in classroom settings, teacher questions are defined as instructional cues or stimuli that convey to student's content elements to be learned and directions for what they are to do and how these elements to be learned and directions for what they are to do and how they are to do it.

The first question is "how do you think about applying questioning strategies in teaching and learning process?". The second question is "what kind of asking strategy that you use in class?". The third question is "is questioning strategy can make you more easy in teaching in front of class?". The fourth question is "is 
Jurnal Onoma: Pendidikan, Bahasa dan Sastra PBSI FKIP Universitas Cokroaminoto Palopo Volume 7 Nomor 1 Tahun 2021
ISSN 2443-3667 (print)

ISSN 2715-4564 (online)

questioning strategy can motivate students in learning?". The fifth question is "how do you know that questioning strategy that you use can motivate the students in teaching and learning process?".

From the data analysis, the researcher found several types of questioning strategies produced by the first teacher, namely "spontaneously answer" which leads to a probing question and "give a variety of unique responses" which leads to a divergent question, and then "yes, that strategy can make it easier when I teach. Because during online learning questions/asking students are reduced due to insufficient time, so the teacher prepares questions that can make students immediately answer quickly" refers to probing question. Then the researcher just found one type of questioning strategy produced by the second teacher, namely "usually I give questions to students in the form of questions that are quite difficult so that students can think more deeply and must answer verbally" which leads to a higher order question.

In this strategy related to the theory by P.E Blosser (1975) probing question is a series question which require students to go beyond the first response. Subsequent teachers' questions are formed on the basic of the students' respond. P.E Blosser (1979) defined that divergent question as question with no right or wrong answer, but which encourage exploration of possibilities. Require both concrete and abstract thinking to arrive and appropriate response. P.E Blosser (in Syarifah, 2017;17) higher order question is question which require students to figure out answers rather than remember them. Requires generalizations related to facts in meaningful patterns.

Based on the theory of P.F Blosser, there are 4 question strategies put forward, namely the probing question, factual question, divergent question and higher order question. These four strategies can make the teaching and learning process effective. And in this research, the researcher found three types of questioning strategies in analyzing data. But the current condition (covid-19) might not be effective anymore if everything is used in the teaching and learning process because considering the insufficient time and also the learning process is carried out during this time so that maybe there will not be enough time the teacher only often uses probing questions, while divergent question higher order question is only given if there is an opportunity but it is still in accordance with the learning material.

\section{Conclusion}

The researcher found that two English teachers at SMKN 7 Luwu Utara used teachers' questioning strategy during teaching and learning process in English learning. In this research, the researcher found as follow:

1. Questioning strategies used by the teacher were probing questions, divergent questions, and higher order questions.

2. As for the strategies that often appears from the four questioning strategies used by the teacher, namely probing questions. 
Jurnal Onoma: Pendidikan, Bahasa dan Sastra PBSI FKIP Universitas Cokroaminoto Palopo Volume 7 Nomor 1 Tahun 2021
ISSN 2443-3667 (print)

ISSN 2715-4564 (online)

\section{References}

Adler, Mortimer, (1982). The paideia proposal: An educational manifesto. NewYork: MacMillan

Alhojailan and Ibrahim, Mohammed. 2012. A Critical Review of Its process and Evaluation. Kingsaud University. Saudi Arabia.

Blosser, P. E (1973). Handbook of effective questioning techniques. Worthington, $\mathrm{OH}$ : Education Associates.

Debra,S.P., \& Barbara, M.T. (2012). Using Higher Order Questioning to Accelerate Students' Growth in Reading. The Reading Teacher Journal. Vol.65 (5).

Faculty, T. H. E., Education, O. F., \& Training, T. (2017). Teacher Questioning Strategies : To Improve Students ' Motivation in English Classroom Learning Activity.

Farmer, L. S. J. (2006). Question as Communication Process.Library, 1-12.

Gay, L. R. 1981. Educational Research: Competencies for Analysis and Application: $2^{\text {nd }}$ Edition. London: Charles E. Merill.

Guest, (1985,P.2). The case study method: Critical thinking enhanced by effective teacher questioning skills. The 18th Annual International Conference of the World Association for Case MethodResearch \& Application.

Harvey, (2000) Teaching Comprehention to Enhance Understanding.

H.DouglasBrown.(2000)[H._Douglas_Brown]_Teaching_by_Principles,_Second_(B ookFi.org).pdf. In Teaching by Principles An Interactive Approach to Language Pedagogy (p. 491).

Hunkin, F. (1976). Involving Students in questioning, Boston : Allyn and Bacon.

Jacobsen, D.,A. at al. (1980). Methods for teaching. New Jersey: Prentice Hall.

Jessica Fries-Gaither (2008) Questioning Tecniques: Research-Based Strategies Teachers. Retrieved on 04 february 2009.

K, G. (2002). A Look at Productive Tutoring Techniques Users Guide. Monitoring Student Learning in The Classroom. (1988).

Long, M. H. and Sato, C.J. (1983) Classroom Foreign Talk Discourse : Forms and Function of Teacher's Questions. TESOL Quarterly. 15.

Lynch, T (1991). Questioning Roles in the Classroom. ELT Journal. 45 (3).

Prabowo, A, B. alfiyanti. (2013). An Analysis of Teachers Questioning Strategis During Interaction In The Classroom.

Riskah. 2019. Improving Students' Vocabulary through Simon Says Game at the Seventh Grade of SMP Negeri 2 Palopo. Unpublish thesis. Palopo: Faculty of Teacher Training and Education - Cokroaminoto Palopo University.

Rosyidah, K. (2018). An Analysis of Teacher' $S$ Questions Used in Classroom Interaction at 11 Th Grade Of Smk Ma 'Arif Nu.

Wade, M. 2006. Likert-Types Scale Response Anchors. Clemson Institute for Tourism \& Research Development, Department of Parks, Recreation and Tourism Management. Unpublish Thesis. Clemson University. 